\title{
Interactive comment on "Proglacial icings as records of winter hydrological processes" by Anna Chesnokova et al.
}

\section{Anna Chesnokova et al. \\ chesnokovaanna@gmail.com \\ Received and published: 11 September 2020}

The comment was uploaded in the form of a supplement:

https://tc.copernicus.org/preprints/tc-2020-63/tc-2020-63-AC1-supplement.pdf

Interactive comment on The Cryosphere Discuss., https://doi.org/10.5194/tc-2020-63, 2020. 